OPEN ACCESS

Edited by:

Martin G. Klotz,

Washington State University Tri-Cities,

United States

Reviewed by:

Peter R. Girguis,

Harvard University, United States

Lisa Y. Stein,

University of Alberta, Canada

Marc Alperin,

University of North Carolina at Chape

Hill, United States

${ }^{*}$ Correspondence:

Ke-Qing Xiao

xiaokeqing12@bios.au.dk

Specialty section:

This article was submitted to

Microbiological Chemistry

and Geomicrobiology,

a section of the journa

Frontiers in Microbiology

Received: 08 February 2017 Accepted: 12 June 2017

Published: 30 June 2017

Citation:

Xiao K-Q, Beulig F, Kjeldsen KU,

Jørgensen $B B$ and

Risgaard-Petersen N (2017)

Concurrent Methane Production and Oxidation in Surface Sediment

from Aarhus Bay, Denmark.

Front. Microbiol. 8:1198.

doi: 10.3389/fmicb.2017.01198

\section{Concurrent Methane Production and Oxidation in Surface Sediment from Aarhus Bay, Denmark}

\author{
Ke-Qing Xiao*, Felix Beulig, Kasper U. Kjeldsen, Bo B. Jørgensen and \\ Nils Risgaard-Petersen
}

Center for Geomicrobiology, Department of Bioscience, Aarhus University, Aarhus, Denmark

Marine surface sediments, which are replete with sulfate, are typically considered to be devoid of endogenous methanogenesis. Yet, methanogenic archaea are present in those sediments, suggesting a potential for methanogenesis. We used an isotope dilution method based on sediment bag incubation and spiking with ${ }^{13} \mathrm{C}_{-} \mathrm{CH}_{4}$ to quantify $\mathrm{CH}_{4}$ turnover rates in sediment from Aarhus Bay, Denmark. In two independent experiments, highest $\mathrm{CH}_{4}$ production and oxidation rates $\left(>200 \mathrm{pmol} \mathrm{cm}^{-3} \mathrm{~d}^{-1}\right)$ were found in the top $0-2 \mathrm{~cm}$, below which rates dropped below $100 \mathrm{pmol} \mathrm{cm}^{-3} \mathrm{~d}^{-1}$ in all other segments down to $16 \mathrm{~cm}$. This drop in overall methane turnover with depth was accompanied by decreasing rates of organic matter mineralization with depth. Molecular analyses based on quantitative PCR and MiSeq sequencing of archaeal 16S rRNA genes showed that the abundance of methanogenic archaea also peaked in the top 0 $2 \mathrm{~cm}$ segment. Based on the community profiling, hydrogenotrophic and methylotrophic methanogens dominated among the methanogenic archaea in general, suggesting that methanogenesis in surface sediment could be driven by both $\mathrm{CO}_{2}$ reduction and fermentation of methylated compounds. Our results show the existence of elevated methanogenic activity and a dynamic recycling of $\mathrm{CH}_{4}$ at low concentration in sulfaterich marine surface sediment. Considering the common environmental conditions found in other coastal systems, we speculate that such a cryptic methane cycling can be ubiquitous.

Keywords: methanogenesis, methane oxidation, surface sediment, methanogenic archaea, isotope dilution

\section{INTRODUCTION}

Methane $\left(\mathrm{CH}_{4}\right)$ generation by methanogenic archaea is the main terminal step in organic matter mineralization in marine sediments depleted of electron acceptors for microbial respiration (Reeburgh, 2007). Three major methanogenic pathways are known based on the type of carbon sources catabolized, i.e., hydrogenotrophic methanogenesis using $\mathrm{CO}_{2}$ and $\mathrm{H}_{2}$, acetoclastic methanogenesis using acetate, and methylotrophic methanogenesis using methylated compounds, such as methanol, methylamines (MAs) or methyl sulfide [dimethyl sulfide (DMS), dimethylsulfoniopropionate (DMSP)] (Whitman et al., 2006). In the presence of sulfate, sulfatereducing bacteria (SRB) usually outcompete methanogens for common substrates like $\mathrm{H}_{2}$ and acetate due to their higher substrate affinity and higher energy yield (Schönheit et al., 1982; Lovley and Klug, 1983). Microbial $\mathrm{CH}_{4}$ production is usually detected in the sub-surface part of marine sediments, where sulfate is depleted. However, as a range of methylated compounds can 
be used by methylotrophic methanogens but generally not by $\mathrm{SRB}$, methanogenesis from these non-competitive substrates is still feasible in surface sediments with high sulfate concentration (Reeburgh, 2007). Such surface sediments receive an influx of detrital organic matter containing different types of molecules, such as lignin, pectin, choline, creatine, and betaine, which can provide a source of methylated substrates for methanogenesis (Oremland et al., 1982; King, 1984; Kiene et al., 1986). Thus, the distribution and activity of methanogens in marine sediments may be controlled not only by competition with SRB for $\mathrm{H}_{2}$ and acetate, but also by the availability of these methylated compounds. In addition to being a metabolic end product, $\mathrm{CH}_{4}$ is also an energy substrate to sulfate, nitrate, iron, and oxygen-respiring microorganisms in shallower sediment layers (Reeburgh, 2007; Knittel and Boetius, 2009; Ettwig et al., 2010, 2016). The upward diffusive flux of $\mathrm{CH}_{4}$ from the methanogenic zone is typically consumed in shallow layers, and $\mathrm{CH}_{4}$ rarely escapes the seafloor (Knittel and Boetius, 2009; Valentine, 2011). Although many studies have suggested that methanogenesis can occur in sulfate-rich environments (Oremland et al., 1982; Mitterer et al., 2001; Mitterer, 2010; Maltby et al., 2016; Zhuang et al., 2016), the magnitude, distribution and pathways of this production remain poorly constrained.

In this study, we quantified concurrent $\mathrm{CH}_{4}$ production and consumption rates using an isotope dilution method based on sediment bag incubation. A previous study showed a downcore distribution of trimethylamine (TMA), DMS, and DMSP concentrations in sediment from the same site in Aarhus Bay, which all peaked in the top few centimeters, and supported the potential for methane generation through the methylotrophic pathway (Zhuang, 2014). We therefore hypothesized that this should be reflected in the downcore distribution of $\mathrm{CH}_{4}$ production in surface sediment of Aarhus Bay, and that the methanogens involved were dominated by methylotrophic groups. As $\mathrm{CH}_{4}$ concentration profiles rarely indicate methanogenesis in surface sediments, we further hypothesize that a cryptic methane cycle exists here in which $\mathrm{CH}_{4}$ production and oxidation is tightly coupled. Such a new prospect of $\mathrm{CH}_{4}$ turnover may challenge current knowledge of carbon cycling in sulfate-rich sediments.

\section{MATERIALS AND METHODS}

\section{Location and Sampling}

The study was performed in Aarhus Bay where organic-rich Holocene marine mud has accumulated up to $>10 \mathrm{~m}$ thick layers on top of the glacial deposits over the past 8000 years (Flury et al., 2016). The sedimentation rate at station $\mathrm{M} 5\left(56^{\circ} 06.20^{\circ} \mathrm{N}\right.$ and $10^{\circ} 27.47^{\circ} \mathrm{E}$; water depth $28 \mathrm{~m}$ ), based on ${ }^{14} \mathrm{C}$-dating of mollusk shells, has been stable for the last 4300 years (Langerhuus et al., 2012). The water column is generally oxic, oxygen penetration depth in the sediment is low (1-5 mm; Rasmussen and Jørgensen, 1992), and bioturbation is visible from sediment color and faunal tracks in the top $3 \mathrm{~cm}$. Sediments for incubation were sampled in December 2015 and May 2016 with a Haps corer (Kanneworff and Nicolaisen, 1972), then transferred into a gravity core liner (diameter $11.8 \mathrm{~cm}$ ) on deck, brought back to the laboratory, kept at in situ temperature, and processed within $48 \mathrm{~h}$. The temperature of the bottom water, measured by thermometer, was around $10^{\circ} \mathrm{C}$ at both sampling times and the salinity was $30 \%$, determined by a handheld refractometer. Rumohr Lot cores (Meischner and Rumohr, 1974) were taken in parallel for geochemical profiles and molecular analysis of the methanogen community, and the sampling intervals were $2 \mathrm{~cm}$ in the top $20 \mathrm{~cm}$. Sediment samples for molecular analysis were taken with sterile $5 \mathrm{ml}$ cut-off plastic syringes and preserved at $-80^{\circ} \mathrm{C}$. Pore-water samples for sulfate and dissolved inorganic carbon (DIC) analysis were extracted from the intact sediment core via Rhizon suction samplers $(0.1 \mu \mathrm{m}$ porous polymer, Rhizosphere Research, Wageningen, Netherlands), pretreated as described previously (Glombitza et al., 2014). Pore-water samples for DIC were kept at $4^{\circ} \mathrm{C}$ before analysis. For sulfate, the extracted pore-water was flushed with $\mathrm{CO}_{2}$ to remove hydrogen sulfide, and frozen at $-20^{\circ} \mathrm{C}$ until analysis. For methane sampling, $3 \mathrm{ml}$ of water close to the sediment surface $(<1 \mathrm{~cm})$ was taken with a $20 \mathrm{ml}$ syringe mounted with a long PVC tube, and $2 \mathrm{ml}$ of sediment was collected with cut-off plastic syringes. All samples were transferred immediately to $10 \mathrm{ml}$ glass serum vials (preloaded with $4 \mathrm{ml}$ distilled water and $1.5 \mathrm{~g} \mathrm{NaCl}$ ), which subsequently were closed with a butyl rubber septum and a crimp cap. The serum vials containing sediment were shaken, and preserved at $-20^{\circ} \mathrm{C}$ before analysis.

\section{Diffusive Fluxes of $\mathrm{CH}_{4}$}

Diffusive fluxes of $\mathrm{CH}_{4}$ were estimated from concentration gradients using Fick's first law:

$$
J=-\varphi /\left(1-\ln \left(\varphi^{2}\right)\right) \times D \times \partial C / \partial z
$$

where $J$ is the diffusive flux of $\mathrm{CH}_{4}, C$ is the concentration, $z$ is depth $(\mathrm{cm})$, and $\varphi$ is porosity (Boudreau, 1997). $D$ is the diffusion coefficient in free solution for a salinity of 30 and temperature of $10^{\circ} \mathrm{C}: \mathrm{D}_{\mathrm{CH} 4}=1.02 \mathrm{~cm}^{2} \mathrm{~d}^{-1}$ (Dale et al., 2008). The factor $1-\ln \left(\varphi^{2}\right)$ corrects for the lower diffusion coefficient in sediment due to tortuosity (Boudreau, 1997).

\section{Bag Incubation Setup and Gas-Tightness Test}

Plastic bags made of gas-tight multi-laminar plastic film (Supplementary Figures S1a, b) (Amcor, Denmark) were used for sediment incubation and ${ }^{13} \mathrm{CH}_{4}$ spiking experiments. This bag incubation method was developed by Hansen et al. (2000), but some modifications were made: (1) the bags were sealed with a black slide binder (LEITZ, Germany) on one side, (2) the silicon gaskets were replaced by butyl rubber gaskets to improve gas tightness (Supplementary Figure S1c), (3) the plastic bags were mounted with a glass outlet custom made to fit the cut-off $2.5 \mathrm{ml}$ syringes (Supplementary Figure S1d), (4) to physically protect the incubation bags and minimize oxygen penetration, they were placed in an outer gas-tight bag filled with $\mathrm{N}_{2}$. Prior to the isotope spiking experiments, gas-tightness tests were conducted by filling bags with artificial sea water brine of $300 \%$ salinity (for inhibiting microbial activities). $\mathrm{CH}_{4}$-saturated artificial sea water was added 
to two parallel bags, leaving no headspace, and incubated at $15^{\circ} \mathrm{C}$. Triplicate samples were taken by syringes with a needle through the stopper and transferred into $3 \mathrm{ml}$ glass vials. Methane in the water samples was measured by the headspace method using gas chromatography (SRI Instruments, United States). Gas-tightness tests were conducted by monitoring $\mathrm{CH}_{4}$ concentration in the bags over time. Within 140 days, methane concentrations in the bag were very stable with little fluctuations (ANOVA, $P>0.05$; Supplementary Figure S2), suggesting that this type of bags can be used for incubation experiments over many days or even months. By this incubation method, sediment is kept in closed bags free of air and headspace and without dilution or stirring. This maintains an environment close to the in situ conditions (Hansen et al., 2000), which is critical for the study of natural process rates.

\section{Bag Incubation and Spiking with ${ }^{13} \mathrm{C}$-Labeled Methane}

The following manipulations were all done under strict anoxic conditions in a glove box (Plas-Lab, Inc., United States), which was continuously flushed with nitrogen gas. Oxygen concentration in the glove box was $<0.5 \mu \mathrm{mol} 1^{-1}$, as monitored with an oxygen sensor (Revsbech, 1989). Sediments from Haps cores were sliced into six $2 \mathrm{~cm}$ segments, five in the top $10 \mathrm{~cm}$, and one around $15 \mathrm{~cm}$. The sliced segments were passed through a $2 \mathrm{~mm}$ sieve to remove macrofauna and hard objects such as carbonate shells which could puncture the bag, and then loaded into the gas-tight bag, carefully avoiding headspace and removing gas bubbles. After $2-3$ days of stabilization, ${ }^{13} \mathrm{C}$-labeled methane was introduced into each bag by injecting $20-100 \mu \mathrm{L}$ of ${ }^{13} \mathrm{CH}_{4}$ containing artificial sea water (excluding sodium sulfate), which resulted in a ${ }^{13} \mathrm{C}$ isotope enrichment of $\sim 2 \%$ with minimal change $(\sim 2 \%)$ of the total $\mathrm{CH}_{4}$ concentrations in pore-water. The sediment was homogenized by manual kneading of the bag for $20 \mathrm{~min}$ (Hansen et al., 2000). Six bags with sediment were incubated at $10^{\circ} \mathrm{C}$ in a thermostated incubator (MMM Incucell, Germany). At each sampling time, triplicate samples were taken by squeezing the bag to push the sediment through the glass outlet, where a PVC tube connected the outlet to a cutoff $2.5 \mathrm{ml}$ syringe to ensure tightness (Supplementary Figure S1d). Sediment collected into the syringe was immediately transferred into $10 \mathrm{ml}$ glass serum vials, which were closed with a butyl rubber septum and crimp cap, and preserved at $-20^{\circ} \mathrm{C}$, as described above.

Methane production and oxidation were calculated from the $\mathrm{CH}_{4}$ concentration and its isotope composition using an isotope dilution model, which was originally developed to determine rates of $\mathrm{NH}_{4}{ }^{+}$turnover in anoxic marine sediments (Blackburn, 1979). The model here presumes that the concentration of $\mathrm{CH}_{4}$ changes during the experiment through time due to constant methane consumption (i.e., oxidation) (r) and production (p), thus:

$$
\mathrm{Ct}=\mathrm{C}_{0}+(\mathrm{p}-\mathrm{r}) \mathrm{t}
$$

The model further presumes that the mole fraction of ${ }^{13} \mathrm{CH}_{4}$ $\left[\mathrm{R}_{\mathrm{t}}={ }^{13} \mathrm{CH}_{4} /\left({ }^{13} \mathrm{CH}_{4}+{ }^{12} \mathrm{CH}_{4}\right)\right]$ changes trough time as a result of production of $\mathrm{CH}_{4}$ from indigenous sources and consumption of $\mathrm{CH}_{4}$ due to anaerobic oxidation in the sediment. In case the rate of methane production, $\mathrm{p}$, is different from rate of methane consumption, $r$, the relationship between $R_{t}$ and time can be described with the following expression:

$$
\ln \left(\mathrm{R}_{\mathrm{t}}-\mathrm{R}_{\mathrm{b}}\right)=\ln \left(\mathrm{R}_{0}-\mathrm{R}_{\mathrm{b}}\right)-(\mathrm{p} /(\mathrm{p}-\mathrm{r})) \ln \left(\mathrm{C}_{\mathrm{t}} / \mathrm{C}_{0}\right)
$$

where $\mathrm{R}_{\mathrm{b}}$ is the mole fraction of ${ }^{13} \mathrm{CH}_{4}$ in $\mathrm{CH}_{4}$ being produced from indigenous sources in the sediment and $\mathrm{R}_{0}$ is the mole fraction of ${ }^{13} \mathrm{CH}_{4}$ at the start of the experiment (see SI for the deduction of Eq. 2, and the equation when $\mathrm{p}=\mathrm{r}$ ). Equation 1 shows that the quantity " $p-r$ " equals the slope of a regression line obtained from plotting $\mathrm{C}_{t}$ against, while Eq. 2 shows that the quantity " $-p /(p-r)$ " equals the slope of a regression line obtained from plotting $\ln \left(\mathrm{R}_{\mathrm{t}}-\mathrm{R}_{\mathrm{b}}\right)$ against $\ln \left(\mathrm{C}_{\mathrm{t}} / \mathrm{C}_{0}\right)$. Therefore $\mathrm{p}$ and $\mathrm{r}$ can each be calculated from the combination of these slopes.

\section{Mineralization of Organic Matters}

The mineralization rates were measured by two methods, (1) during both cruises, sulfate reduction rates (SRRs) were determined the using the whole-core injection method (Jørgensen, 1978). Two microliters of carrier-free ${ }^{35} \mathrm{~S}$-sulfate solution containing approximately $100 \mathrm{kBq}$ (ca. $2.5 \mu \mathrm{Ci}$ ) of radioactivity, were injected in $2 \mathrm{~cm}$ intervals at multiple depths in 26-mm-i.d. core. The formation of radiolabeled products was analyzed after incubation for $12-19 \mathrm{~h}$ at the in situ temperature. Incubations were terminated by sectioning the core into $2 \mathrm{~cm}$ segments that were fixed in weighed vials containing $10 \mathrm{ml}$ of cold 5\% $\mathrm{Zn}$-acetate. The sediment was immediately mixed and stored at $-20^{\circ} \mathrm{C}$ up to 4 weeks until further analysis. After thawing, the total reduced inorganic sulfur (TRIS $=\mathrm{H}_{2} \mathrm{~S}, \mathrm{~S}_{0}$, $\mathrm{FeS}$, and $\mathrm{FeS}_{2}$ ) was separated from the ${ }^{35} \mathrm{SO}_{4}{ }^{2-}$ by a single step cold chromium distillation (Kallmeyer et al., 2004). The radioactivity of ${ }^{35} \mathrm{SO}_{4}{ }^{2-}$ and ${ }^{35}$ S-TRIS was counted in $15 \mathrm{ml}$ scintillation cocktail (Gold Star, Meridian Biotechnologies, United Kingdom) on a TriCarb 2900TR liquid scintillation analyzer (Packard Instrument Company, Germany). The ex situ SRRs were then calculated accordingly with a correction factor of 1.06 (Jørgensen, 1978; Flury et al., 2016); (2) In May 2016, accumulation of ammonium $\left(\mathrm{NH}_{4}{ }^{+}\right)$and DIC were also monitored in the bags to estimate mineralization rates. Sediment subsamples of $2.5 \mathrm{ml}$ were taken from each bag and centrifuged, $\mathrm{NH}_{4}{ }^{+}$, DIC, and calcium were analyzed in the supernatant. The $\mathrm{Ca}^{2+}$ concentrations in sediment during the incubation were quite stable with little change over time (ANOVA, $P>0.05$ ). The production rates of $\mathrm{NH}_{4}{ }^{+}$and DIC were calculated by plotting concentrations against time and using linear fitting, and production rates of $\mathrm{NH}_{4}{ }^{+}$were multiplied by a factor of 1.3 to correct for adsorption, according to Canfield et al. (1993a). The rates of organic carbon mineralization rates from SRR were calculated with a 1:2 stoichiometry between SRR and organic C oxidation (Flury et al., 2016). 


\section{Chemical Analysis}

Methane was measured using a Gas Chromatograph (GC) (310C, SRI Instruments, United States) with a flame ionization detector. The carbon isotope composition of methane was determined using a coupled pre-concentration GC/Isotope Ratio Mass Spectrometer system (GC/IRMS) (Thermo Fisher Scientific, Germany) (Rice et al., 2001). The $\delta^{13} \mathrm{C}$ values were reported vs. the Vienna Pee Dee Belemnite standard (VPDB). DIC was measured on the same GC/IRMS system without pre-concentration (Torres et al., 2005). Sulfate was measured by an IC-2500 ion chromatography system (Dionex Corporation, United States), $\mathrm{NH}_{4}{ }^{+}$was determined by a FLUOstar Omega spectrophotometer (BMG LABTECH, Germany) based on the salicylate-hypochlorite method (Bower and Holm-Hansen, 1980), and calcium was measured by inductively coupled plasma optical emission spectrometry (ICP-OES) (Perkin Elmer Optima 2000DV, United States).

\section{DNA Extraction, Amplification, and Sequencing}

Aliquots of frozen sediment samples $(0.2 \mathrm{~g})$ from the parallel Rumohr Lot core were used for total DNA extraction. Sediment samples were thawed at room temperature in a lysis buffer mixture containing $0.65 \mathrm{ml}$ sodium phosphate buffer solution (112.9 $\mathrm{mM} \mathrm{Na}_{2} \mathrm{HPO}_{4}, 7.1 \mathrm{mM} \mathrm{NaH} \mathrm{PO}_{4}$ ) and $0.2 \mathrm{ml}$ SDS solution $(500 \mathrm{mM}$ Tris- $\mathrm{HCl}, 100 \mathrm{mM} \mathrm{NaCl}, 10$ w.-\% sodium dodecyl sulfate, $\mathrm{pH} 8.0)$, as well as $0.25 \mathrm{ml}$ zirconia beads $(0.1 \mathrm{~mm}$ diameter, BioSpec, United States). The thawed mixture was subjected to bead beating at 50 oscillations $\mathrm{s}^{-1}$ for $1 \mathrm{~min}$ using a TissueLyser LT 2500 (Qiagen, Germany), followed by incubation in a thermomixer with $600 \mathrm{rpm}$ at $50^{\circ} \mathrm{C}$. After lysis, the mixture was centrifuged for $10 \mathrm{~min}$ at $19,000 \times g$ at $4^{\circ} \mathrm{C}$. The supernatant was extracted with equal volumes of phenol:chloroform:isoamyl alcohol (25:24:1, vol:vol:vol; Sigma Aldrich, United States), followed by extraction with equal volumes of chloroform: isoamyl alcohol (24:1, vol:vol; Sigma Aldrich, United States). DNA was precipitated with $1 \mathrm{ml}$ polyethylene glycol 8,000 (Sigma Aldrich, United States) at $4^{\circ} \mathrm{C}$ overnight, centrifuged at $19,000 \times g$ for $30 \mathrm{~min}$. The precipitates were washed with ice cold 70 vol\% ethanol solution, dried up in the air and then dissolved in $400 \mu \mathrm{l}$ TE buffer (10 mM Tris, $1 \mathrm{mM}$ EDTA, $\mathrm{pH} 8.0$ ) and stored at $-20^{\circ} \mathrm{C}$ before use.

Abundances of archaeal 16S rRNA genes were determined on LightCycler 480 (Roche, US) using the primer sets Arch 806F (ATT AGA TAC CCS BGT AGT CC) (Takai and Horikoshi, 2000) and Arch 958R (YCC GGC GTT GAM TCC AAT) (DeLong, 1992). A fragment covering the hypervariable regions (V3-V6) of the Archaeal 16S rRNA gene were PCR amplified using the primers Arch344Fmod (5'-GGGYGCAGCAGKCGMGAA-3') and Arch915R (5'-GTGCTCCCCCGCCAATTCCT-3') (Goodfellow and Stackebrandt, 1991). The forward primer was modified from the initial primer Arch349F (5'-GYGCASCAGKCGMGAAW$3^{\prime}$; Takai and Horikoshi, 2000) by extending the $5^{\prime}$-end and reducing degeneracy without losing coverage as determined by in silico tests using TestPrime 1.0 (Klindworth et al., 2013).
PCR was carried out in $25 \mu$ l reaction volume with GeneAmp 9700 Thermal Cycler (Applied Biosystems, United States) with the following cycling parameters, initial pre-denaturation at $98^{\circ} \mathrm{C}$ for $2 \mathrm{~min}$, followed by 25 cycles of denaturation at $95^{\circ} \mathrm{C}$ for $30 \mathrm{~s}$, annealing at $60^{\circ} \mathrm{C}$ for $45 \mathrm{~s}$, elongation at $72^{\circ} \mathrm{C}$ for $1 \mathrm{~min}$, plus a final extension at $72^{\circ} \mathrm{C}$ for $10 \mathrm{~min}$. The PCR mixture contained $0.125 \mu \mathrm{l}$ TaKaRa ExTaq Hot Start polymerase (TaKaRa, Japan), $2.5 \mu \mathrm{l}$ of $10 \times$ Ex Taq buffer, $2 \mu \mathrm{l}$ dNTP solution $(2.5 \mathrm{mM}), 1 \mu \mathrm{l}$ of each primer $(10 \mu \mathrm{M}), 2 \mu \mathrm{l} \mathrm{BSA}\left(10 \mu \mathrm{g} \mu \mathrm{l}^{-1}\right), 1 \mu \mathrm{l}$ of template DNA, and $15.375 \mu \mathrm{l}$ de-ionized ultrapure water. In a second PCR, all PCR products were supplied with the forward and reverse Illumina ${ }^{\circledR}$ adapter overhang sequences, which are provided in Illumina ${ }^{\circledR}$ published "16S metagenomic sequencing Library preparation protocol". The resultant PCR products were purified and supplied with indices using the Illumina ${ }^{\circledR}$ Nextera XT Index Kit. Negative controls without template were included to test for reagent contamination in each set of PCR reactions. PCR products were evaluated on $2 \%$ agarose gels, and purified using the Agencourt AMPure XP Kit (Beckman Coulter, Inc., United States) before used as template for the next PCR. The final purified PCR products were quantified by a Qubit 2.0 fluorometer with the dsDNA HS Assay Kit (Life Technologies, United States), and then pooled in an equimolar ratio. The pooled library was sequenced on an Illumina ${ }^{\circledR}$ MiSeq system using a 600 cycle MiSeq v3 Reagent Kit (Illumina, United States), which produces two 300-bp long paired-end reads. An average of 39,026 (ranging from 16,477 to 66,068) reads were generated for all samples, and more than $99.7 \%$ of them classified as archaea, thus indicating good specificity of the primers.

\section{Quality-Filtering and Sequence Analysis}

The paired-end MiSeq reads were processed using MOTHUR 1.36.1 (Schloss et al., 2009) by following the MiSeq SOP pipeline (Kozich et al., 2013). Merged reads with length shorter than 540 bp or longer than 599 bp, or homopolymeric stretches longer than $7 \mathrm{bp}$ were all removed from the dataset in the initial quality filtering. Reads were further denoised by preclustering and the chimeric sequences were checked and filtered out by UCHIME (Edgar et al., 2011). The filtered sequences were aligned and classified based on the SILVA SSU REF NR v.123 database (Quast et al., 2013; Yilmaz et al., 2014). Sequences not aligning within the expected region flanked by the PCR primers were removed from further analysis. Methanogen taxonomic lineages were classified into different physiological categories depending on their presumed substrate preference (Canfield et al., 2005; Jabłoński et al., 2015): hydrogenotrophic $\left(\mathrm{H}_{2}\right)$ using $\mathrm{H}_{2} / \mathrm{CO}_{2}$, acetoclastic (Acetate) using acetate, methylotrophic (Methyl) using non-competitive methylated substrates (MAs, methanol, etc.), mixotrophic (Mix) using more than one type of substrates, and unclassified $(\mathrm{N})$. The sequences generated in this study were deposited in the NCBI Sequence Read Archive (SRA) under project no. PRJNA359637.

\footnotetext{
${ }^{1}$ http://support.illumina.com
} 


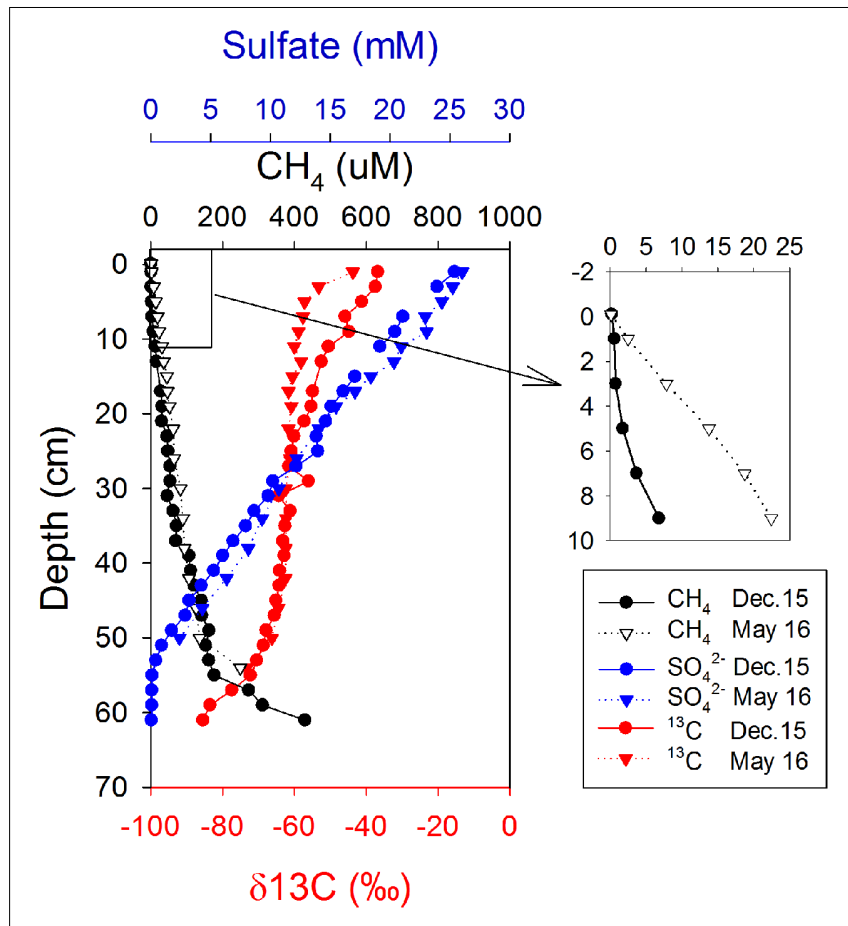

FIGURE 1 | Depth distributions of sulfate, methane, and $\delta^{13} \mathrm{C}$ of methane on two sampling occasions.

\section{RESULTS}

\section{Geochemical Profiles}

Profiles of geochemical parameters showed similar pattern in cores from the two cruises in December 2015 and May 2016 (Figure 1). Methane pore-water concentrations increased with depth, from 0.6 to $51 \mu \mathrm{M}$ in the top $20 \mathrm{~cm}$, where the sulfate concentration was $>15 \mathrm{mM}$. There was a slight gradient of $\mathrm{CH}_{4}$ from the sediment to the overlying seawater (Figure 1, enlarged section). The gradient was used to calculate diffusive methane fluxes across the sediment-water interface using Fick's first law. The estimated methane flux was $0.22 \mathrm{nmol} \mathrm{cm} \mathrm{cm}^{-2} \mathrm{~d}^{-1}$ during December and $2.13 \mathrm{nmol} \mathrm{cm}{ }^{-2} \mathrm{~d}^{-1}$ during May (Table 1). This is a minimal estimate, as the effect of bioturbation was not taken into account. The sulfate-methane transition zone was shallow, at around $50 \mathrm{~cm}$, but there was a long tailing of methane up through the sulfate zone. The $\delta^{13} \mathrm{C}$ of methane decreased with depth from $-30 \%$ to $-80 \%$ in both profiles, with a small shift to more negative values in the top $20 \mathrm{~cm}$ for the May samples.

\section{Dynamics of Methane and Isotopes during Incubation}

The initial concentration of $\mathrm{CH}_{4}$ in each bag did not increase with depth as it did in $\mathrm{CH}_{4}$ profiles, which was due to loss of $\mathrm{CH}_{4}$ during slicing and sieving. During incubations, the concentrations of $\mathrm{CH}_{4}$ decreased with time for all depths except for the $0-2 \mathrm{~cm}$ (Figure 2). In this top section, $\mathrm{CH}_{4}$ increased from 1.7 to $1.9 \mu \mathrm{M}$ over the first 4 days, and then decreased with a similar trend as at other depths. This is consistent with the idea that that some active substrates were available in the top 0-2 cm for methanogenesis, which became depleted rapidly in a few days. Therefore, at $0-2 \mathrm{~cm}$ the modeling and calculation of methane turnover rates was separated in two phases, 0-4 days and 6-50 days. The $\delta^{13} \mathrm{C}$ values decreased with time in all incubations (Figure 2), as evidence of methane production from a non-spiked carbon source (Seifert et al., 2006). Similar patterns of $\mathrm{CH}_{4}$ concentrations and $\delta^{13} \mathrm{C}$ values were displayed during bag incubations in May (Supplementary Figure S3).

\section{Rate Calculations Based on Isotope Dilution Model}

As assumed by the isotope dilution model, the correlation coefficients were all above 0.96 by linearly fitting $\mathrm{CH}_{4}$ concentrations with time (Figure 3). The validity of the model is more significantly corroborated by the linearity demonstrated by the plots of $\ln \left(\mathrm{R}-\mathrm{R}_{\mathrm{b}}\right)$ against $\ln \left(\mathrm{C}_{\mathrm{t}} / \mathrm{C}_{0}\right)$, and the correlation coefficients were all above 0.95. Similar trends and good fitting were also observed in experiments repeated in May 2016 (Supplementary Figure S4), and in the second phase of 0-2 cm (Supplementary Figure S5). Based on the modeling data, production and oxidation rates of $\mathrm{CH}_{4}$ were calculated (Figure 4). Both production and oxidation rates peaked in the top layer with initial rates of over $200 \mathrm{pmol} \mathrm{cm}^{-3} \mathrm{~d}^{-1}$, and then decreased steeply to below $100 \mathrm{pmol} \mathrm{cm}^{-3} \mathrm{~d}^{-1}$ in all other layers, with no clear depth trend. Also during the second phase in 0 $2 \mathrm{~cm}$, rates were $<100 \mathrm{pmol} \mathrm{cm} \mathrm{cm}^{-3} \mathrm{~d}^{-1}$. The depth-integrated rates of $\mathrm{CH}_{4}$ production and oxidation were slightly higher in December 2015 compared to May 2016 (Table 1), which were all around $1 \mathrm{nmol} \mathrm{cm}{ }^{-2} \mathrm{~d}^{-1}$ in $0-16 \mathrm{~cm}$.

\section{Mineralization Rates}

The highest SRRs of up to $100 \mathrm{nmol} \mathrm{cm}{ }^{-3} \mathrm{~d}^{-1}$ were detected at $0-2 \mathrm{~cm}$ in December 2015, and then decreased gradually to below $20 \mathrm{nmol} \mathrm{cm}^{-3} \mathrm{~d}^{-1}$ at $17.5 \mathrm{~cm}$ (Figure 5, left panel). In May 2016, a similar distribution of SRR with depth was observed, while the SRR were slightly higher at each depth compared to December 2015 (Figure 5, left panel). The rates of organic carbon mineralization rates calculated from SRR gave values close to production rates of DIC (Figure 5, right panel, and Supplementary Figure S6), except at $0-2 \mathrm{~cm}$, where the DIC production rate $\left(290 \mathrm{nmol} \mathrm{cm} \mathrm{cm}^{-3} \mathrm{~d}^{-1}\right)$ was higher than the mineralization rate calculated only from SRR. The depthintegrated rates of SRR and carbon mineralization were two to

TABLE 1 | Depth-integrated $(0-16 \mathrm{~cm})$ rates of different processes in surface sediments of this study.

\begin{tabular}{|c|c|c|}
\hline Processes (rates) & December 2015 & May 2016 \\
\hline $\mathrm{CH}_{4}$ flux $\left(\mathrm{nmol} \mathrm{cm}{ }^{-2} \mathrm{~d}^{-1}\right)$ & 0.22 & 2.13 \\
\hline $\mathrm{CH}_{4}$ production $\left(\mathrm{nmol} \mathrm{cm} \mathrm{cm}^{-2} \mathrm{~d}^{-1}\right)$ & 1.00 & 0.83 \\
\hline $\mathrm{CH}_{4}$ oxidation $\left(\mathrm{nmol} \mathrm{cm}-2 \mathrm{~d}^{-1}\right)$ & 1.11 & 0.93 \\
\hline Sulfate reduction ( $\mathrm{nmol} \mathrm{cm}^{-2} \mathrm{~d}^{-1}$ ) & 553.53 & 623.34 \\
\hline DIC production ( $\mathrm{nmol} \mathrm{cm}^{-2} \mathrm{~d}^{-1}$ ) & - & 1080.41 \\
\hline
\end{tabular}



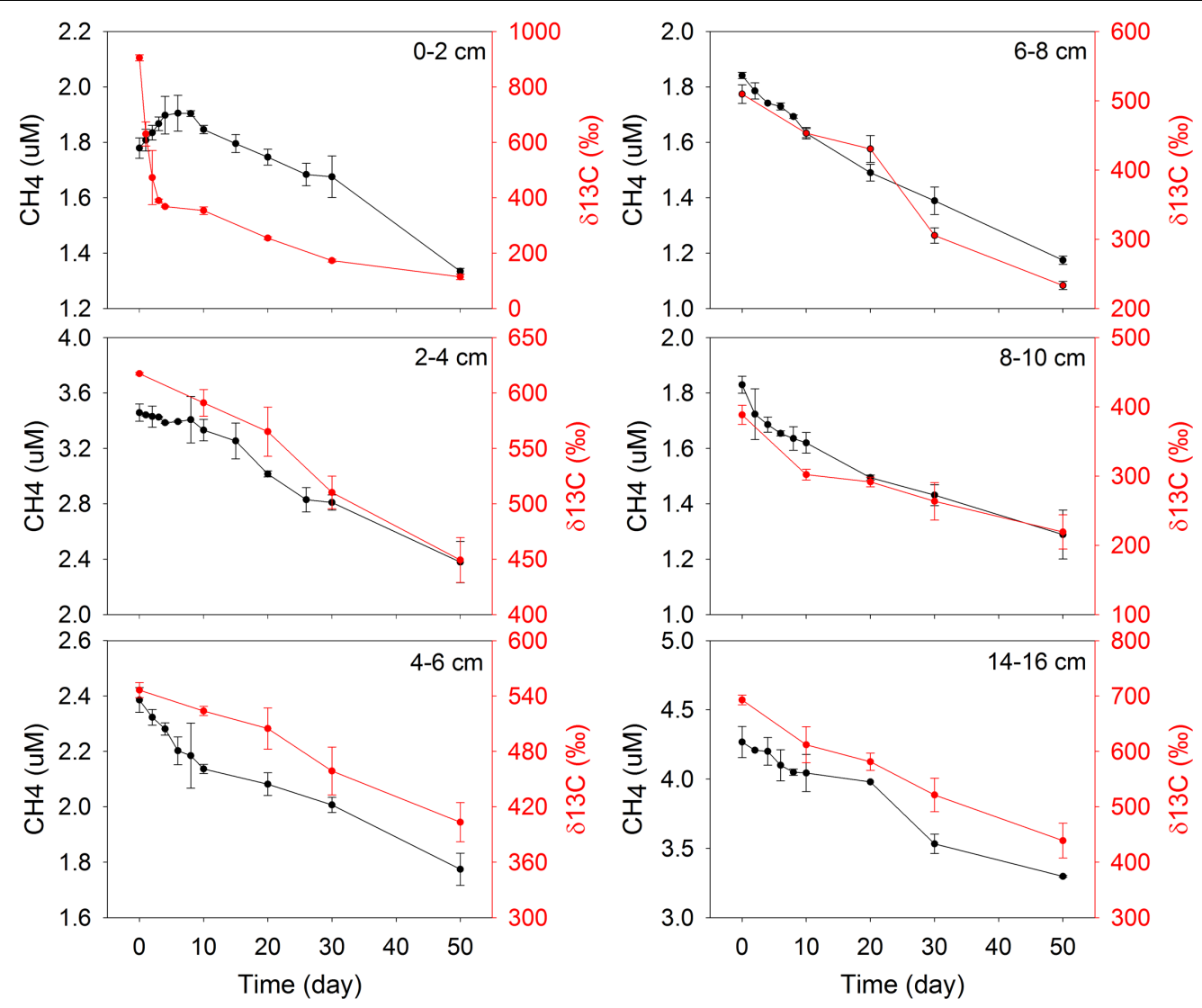

FIGURE 2 | Concentration and ${ }^{13} \mathrm{C}$ isotopic composition of $\mathrm{CH}_{4}$ in the bags during incubation of December samples.

three orders of magnitude higher than both flux and turnover rates of $\mathrm{CH}_{4}$ in $0-16 \mathrm{~cm}$ (Table 1).

\section{Methanogens in the Surface Sediment}

The in situ archaeal communities and their depth distribution were similar at the phylum level during the two sampling occasions (Supplementary Figure S7), and dominated by Woesearchaeota, Euryarchaeota, Thaumarchaeota, and Bathyarchaeota (formerly known as the Miscellaneous Crenarchaeotal Group) (Meng et al., 2014). The relative abundances of Bathyarchaeota were constant with depth at around $10 \%$ of all Archaea, but no methanogens were classified into this phylum due to lack of taxonomy information at lower levels. Methanogenic archaea belonging to Euryarchaeota were present throughout the surface sediment, where their relative abundances (reads classified as methanogens/all reads) were generally less than $1.4 \%$ of all Archaea (Figure 6). Thus, the absolute abundances of methanogens, estimated by multiplying their relative abundances with total archaeal 16S rRNA gene copies, were two orders of magnitude lower than the total archaeal communities. Both the relative abundances and absolute abundances of methanogens decreased with depth, except at around $13 \mathrm{~cm}$ (Figure 6). Most methanogenrelated sequences in the surface sediments belonged to unclassified Methanomicrobiales, Methanococcoides, and
Methermicoccus (Supplementary Figure S8). The distribution of methanogens classified according to their inferred metabolic type is summarized in Figure 7, and hydrogenotrophic and methylotrophic methanogens dominated in all samples, while putative acetoclastic methanogens appeared only in a few samples with low abundances. A minor proportion of methanogens could not be assigned to a specific metabolic type.

\section{DISCUSSION}

Bag incubation of sediment combines the merits of slurry incubations with jars and whole-core incubations, and provides low heterogeneity close to natural conditions during anoxic incubation of sediment (Hansen et al., 2000). This bag incubation method has proven to be a useful tool in the study of anaerobic biogeochemical processes, such as degradation of organic matter, iron reduction, manganese reduction, and sulfate reduction (Canfield, 1989; Canfield et al., 1993a,b; Thamdrup and Canfield, 1996; Hansen et al., 1998, 2000). Here we extend this method to quantify $\mathrm{CH}_{4}$ turnover by combing it with an isotope dilution technique. For a gas like $\mathrm{CH}_{4}$, it is critical to avoid air pockets in the bag, as even a small headspace might cause a significant loss of $\mathrm{CH}_{4}$ from pore-water into the gas phase (Yamamoto et al., 1976). Our method calculates methane turnover rates 

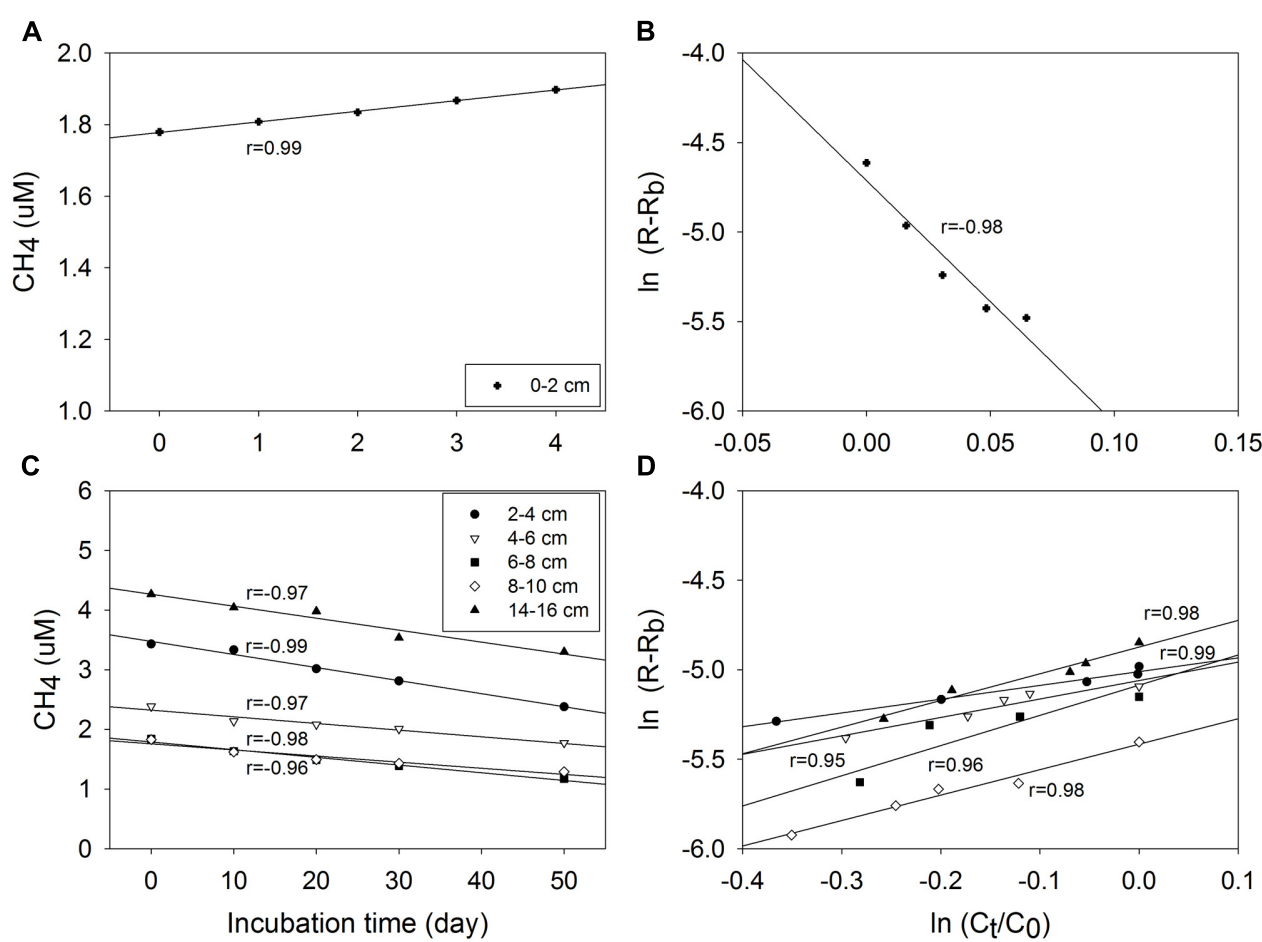

FIGURE 3 | Plot and linear fitting of total $\mathrm{CH}_{4}$ concentrations $\left(\mathrm{C}_{\mathrm{t}}\right)$ and ${ }^{13} \mathrm{C}-\mathrm{CH}_{4}$ relative abundance (R) during incubation of sediment samples from December 2015 total $\mathrm{CH}_{4}\left(\mathrm{C}_{t}\right)$ concentration against incubation time $(\mathbf{A}, \mathbf{C})$, and $\ln \left(\mathrm{R}-\mathrm{R}_{\mathrm{b}}\right)$ against $\left.\ln \left(\mathrm{C}_{t} / \mathrm{C}_{0}\right) \mathbf{( B , D}\right), \mathrm{R}_{\mathrm{b}}$ is the mole fraction of ${ }^{13} \mathrm{CH}_{4}$ in $\mathrm{CH}_{4}$ being produced from indigenous sources in the sediment.

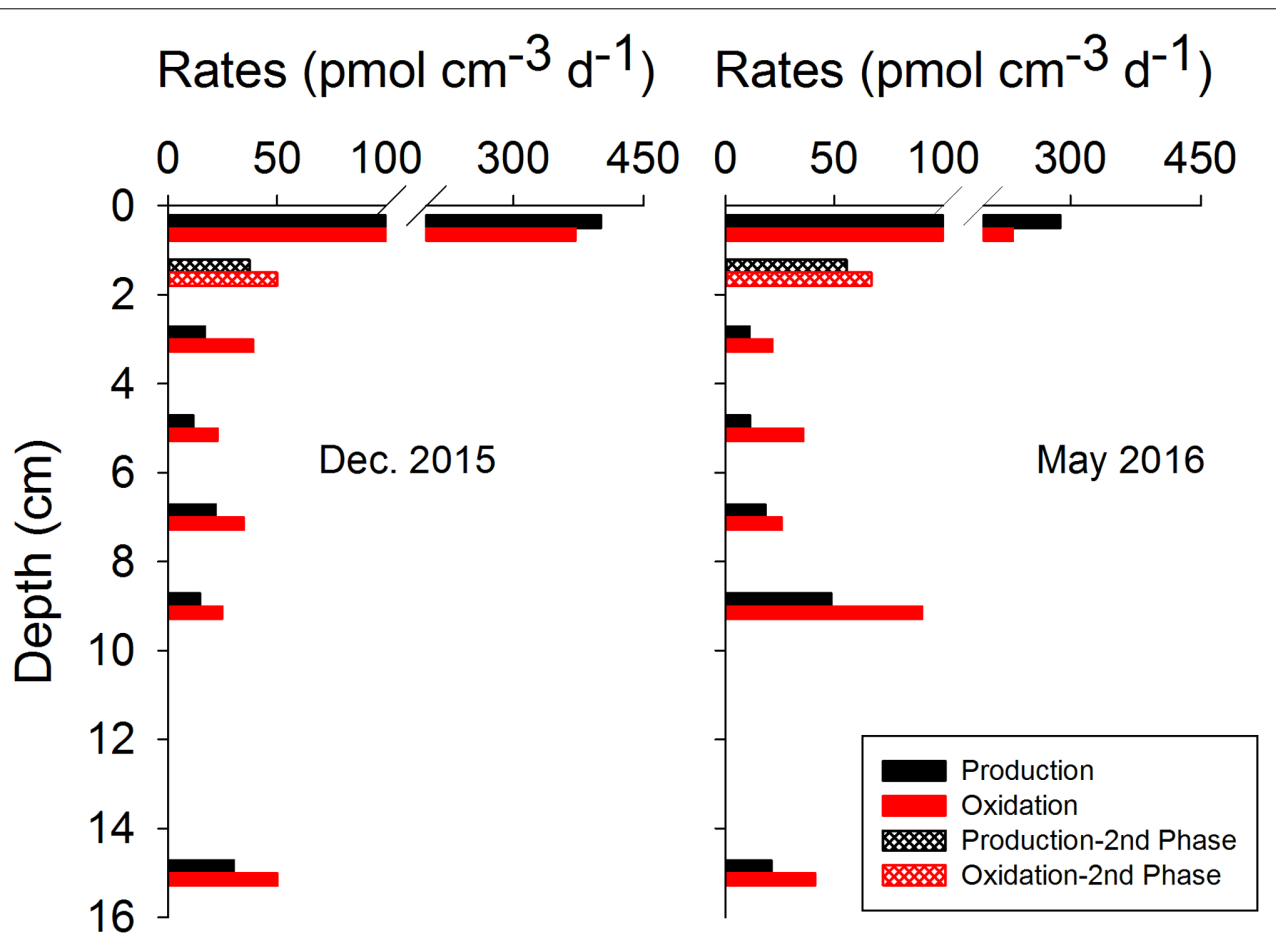

FIGURE 4 | Depth distributions of $\mathrm{CH}_{4}$ production and oxidation rates in December 2015 (left panel) and May 2016 (right panel), as calculated from bag incubation data of total $\mathrm{CH}_{4}$ concentrations and ${ }^{13} \mathrm{C}-\mathrm{CH}_{4}$ relative abundance. 


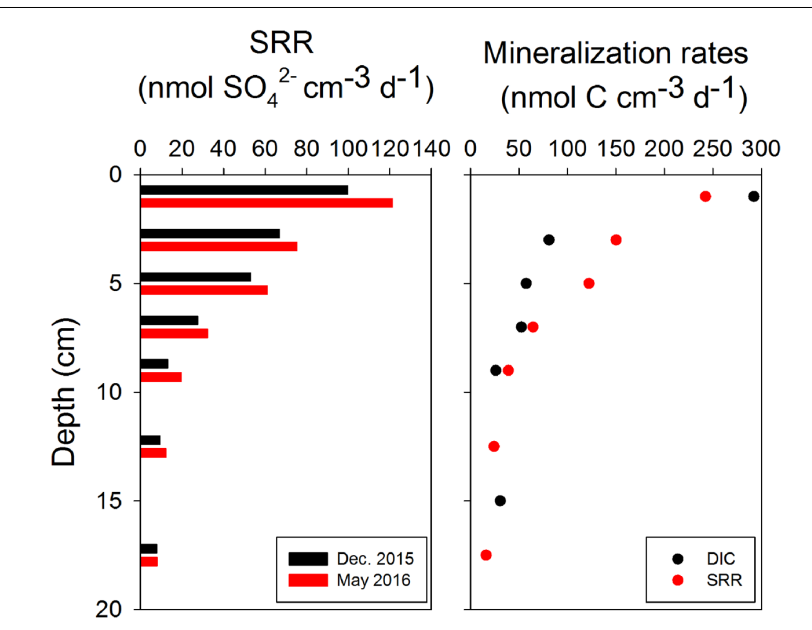

FIGURE 5 | Sulfate reduction rates (SRR) in surface sediments from December and May cruises (left panel), and carbon mineralization rates calculated from production of DIC in bags and SRR in the core 1 : 2 stoichiometry between SRR and organic C oxidation rates) in May 2016 (right panel).

during an incubation period, and thus averages out some finer temporal variations that may occur. Therefore, information about non-constant rates is lost, but few artifacts are created. The sieving of sediment before incubation and kneading of bag before each sampling aims to make sediment homogeneous in the bag, which allows repeated sampling during a time-course experiment (Hansen et al., 2000). However, these operations inevitably alter the structure of the original sediment, and may influence the rates of $\mathrm{CH}_{4}$ turnover and sulfate reduction, for example, influx of oxidants through bioturbation and bioirrigation is blocked in bag incubations, which could stimulate sulfate reduction. Hansen et al. (2000) found that in the deeper part of sediment or those sediments with low oxygen penetration depth, whole-core and bag based SRR were quite close, while bagrates exceeded whole-core rates by 1.4 - to 3.2-fold in the more oxidized sediment. Thamdrup and Canfield (1996) found that carbon mineralization rates in bag incubations were close to rates from flux measurements in sediment core in continental margin sediments off central Chile, and Hansen et al. (1998) reported that anaerobic methane oxidation rates based on ${ }^{14} \mathrm{CH}_{4}$ labeling in bag incubations were similar to rates in intact sediment core in Norsminde Fjord, Denmark. In our study, the sediment has a low oxygen penetration depth (Rasmussen and Jørgensen, 1992) and the majority of macro fauna were removed during sieving, which minimized the effect of degradation of entombed fauna (Canfield et al., 1993a), and hence we take the rates from bag incubation as estimates for in situ sediment metabolism. Our latest measurements in new samples from the same site confirmed that SRR and methanogenesis rates (based on ${ }^{14} \mathrm{CO}_{2}$ labeling) determined in incubation bags were quite close to rates determined in intact sediment cores (Xiao et al., in preparation).

In spite of potential for methanogenesis in surface sediment which has been demonstrated by several earlier studies (Oremland et al., 1982; King, 1984; Mitterer et al., 2001; Maltby

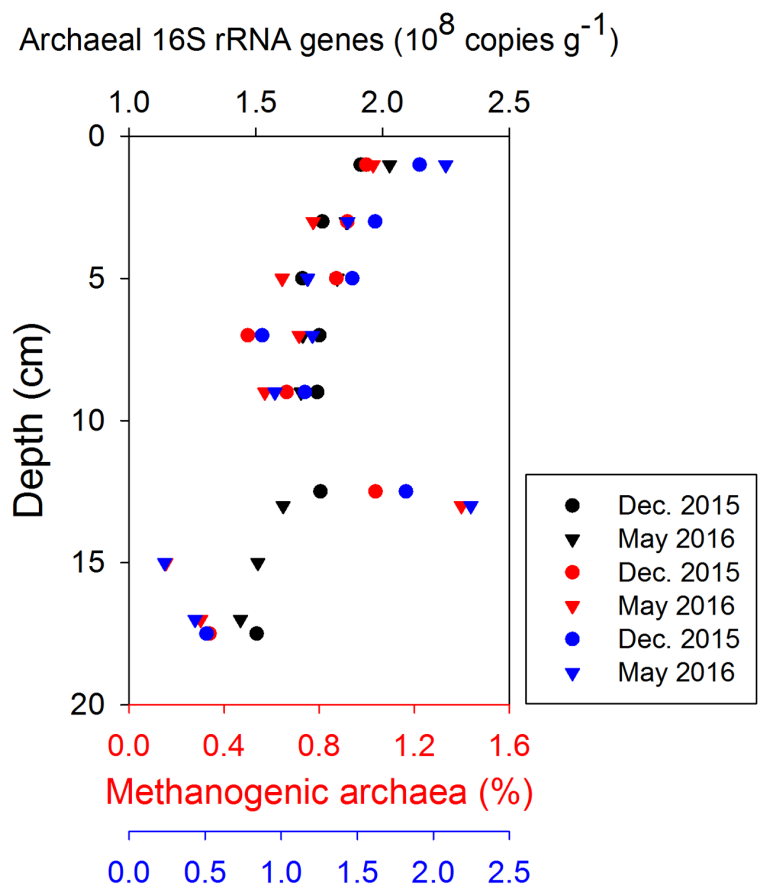

Methanogenic archaea $\left(10^{6}\right.$ copies $\left.\mathrm{g}^{-1}\right)$

FIGURE 6 | Depth distributions of archaea abundance (qPCR of 16S rRNA, in black), the relative abundance of methanogens (i.e., reads classified as methanogens/all archaeal reads, in red), and the absolute abundance of methanogens in the top 0-20 cm (estimated by multiplying their relative abundances with total archaeal 16S rRNA gene copies, in blue).

et al., 2016; Zhuang et al., 2016), methane production is seldom reflected in the geochemical profiles of $\mathrm{CH}_{4}$ due to a characteristic concave-up shape most of the time, which is thought to be an indication of diffusion combined with net $\mathrm{CH}_{4}$ oxidation (Iversen and Blackburn, 1981; Alperin et al., 1988). The closely coupled $\mathrm{CH}_{4}$ production and oxidation in surface sediment in our study (Figure 4) may partially explain this. Methane production almost balanced methane oxidation so that a cryptic cycling of $\mathrm{CH}_{4}$ existed, leaving little imprint in the pore water chemistry. One of the general signatures of biogenic $\mathrm{CH}_{4}$ is that $\delta^{13} \mathrm{C}$ values are more negative than $-50 \%$ (Reeburgh, 2007), yet the $\delta^{13} \mathrm{C}$ values were around $-30 \%$ in the top $2 \mathrm{~cm}$ of sediment in the present study (Figure 1), elevated rates of $\mathrm{CH}_{4}$ oxidation obviously contributed to this enriched ${ }^{13} \mathrm{C}$. The substrate limitation effects on the $\delta^{13} \mathrm{C}$ of $\mathrm{CH}_{4}$ locally produced may play a role too, which was found in hypersaline microbial mats, and can be reversed by organic matter addition (Oremland et al., 1982; Kelley et al., 2014, 2015). The bag incubation method combined with the isotope dilution technique used here makes it possible to estimate $\mathrm{CH}_{4}$ production and oxidation rates simultaneously (Blackburn, 1979; Andersen et al., 1998; von Fischer and Hedin, 2002), which makes it possible to directly quantify $\mathrm{CH}_{4}$ turnover rates close to in situ conditions. The methanogenesis rates in surface sediment from Aarhus Bay are comparable to those quantified by ${ }^{14} \mathrm{C}$-labeled substrates in the shallow sediments of 


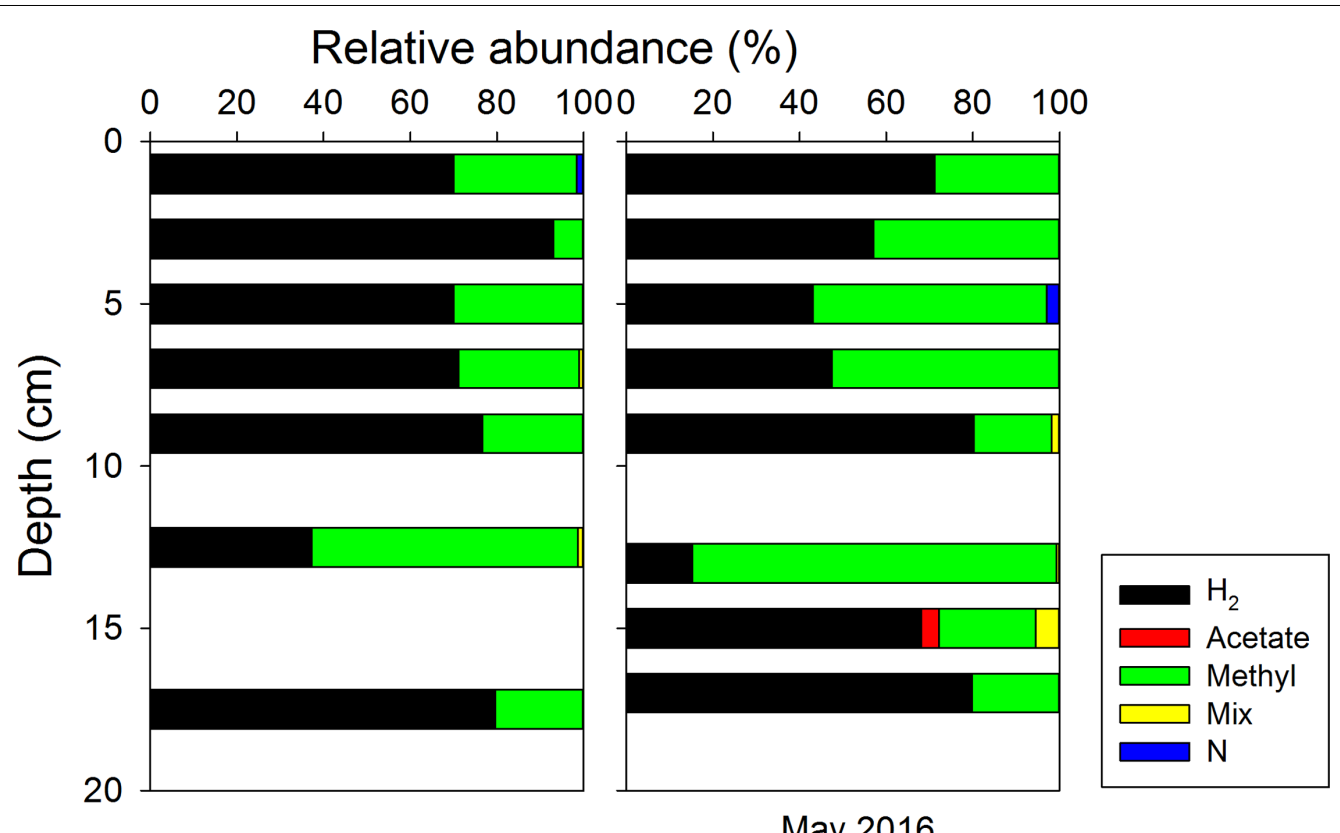

FIGURE 7 | Depth distributions of different groups of methanogens classified according to presumed substrate usage: hydrogenotrophic $\left(\mathrm{H}_{2}\right)$ using $\mathrm{H}_{2} / \mathrm{CO}_{2}$, acetoclastic (Acetate) using acetate, methylotrophic (Methyl) using non-competitive methylated substrates, mixotrophic (Mix) that may use more than one type of substrates, and unclassified (N).

the Sonora Margin cold seeps, where rates peaked at 617 and 333 pmol cm $\mathrm{cm}^{-3} \mathrm{~d}^{-1}$, respectively in the top $7 \mathrm{~cm}$ of two sites, and then decreased with depth (Vigneron et al., 2015). In sediments in the Peruvian margin with low-oxygen conditions and frequent input of fresh organic matter, net methanogenesis rates of $0.03-$ $0.1 \mathrm{mmol} \mathrm{m}^{-2} \mathrm{~d}^{-1}$ over 0-25 cm (Maltby et al., 2016) was found by measuring $\mathrm{CH}_{4}$ increase in headspace of incubation vials, corresponding to averages of $0.12-0.4 \mathrm{nmol} \mathrm{cm}^{-3} \mathrm{~d}^{-1}$.

Methane production rates peaked at $0-2 \mathrm{~cm}$ depth and dropped below as did SRR and organic matter mineralization rates (Figures 4, 5), suggesting a pool of more degradable organic substrates near the sediment surface. However, thermodynamically, sulfate reducers are expected to outcompete methanogens in the sulfate-rich sediment for common substrates like acetate and hydrogen (Lovley and Goodwin, 1988; Hoehler et al., 1998). An enhanced $\mathrm{CH}_{4}$ production in the top layer may be unexpected because SRRs are also high in this layer (Figure 5). A possible explanation is that methylotrophic (non-competitive) methanogens could use non-competitive substrates like MA, DMS, and methanol as the dominant pathway (Oremland et al., 1982; King, 1984; Mitterer et al., 2001; Mitterer, 2010; Vigneron et al., 2015; Zhuang et al., 2016). These small organic compounds are ubiquitous in the marine environment, and originate from the decomposition of substances like choline, creatine and betaine, lignins and pectin, or from bacterial reduction of TMA oxide (Yancey and Somero, 1980; Oremland et al., 1982; Alcolombri et al., 2015). The downcore distribution of a large exchangeable pool of TMA $\left(0.3-6.5 \mu \mathrm{mol} \mathrm{kg}{ }^{-1}\right)$ at the same site as this study implied an endogenous source of this substrate. The free pools of methylated substrates in the pore water were extremely low, however, with only a few nanomolar DMS (DMSP) and no detectable $(<20 \mathrm{nM})$ free TMA in the pore-water (Zhuang, 2014). Yet, methanogenesis from these compounds with so low concentrations was still energetically favorable (Zhuang, 2014; Zhuang et al., 2016). The high affinity of some of these methylated compounds to solid phase (Wang and Lee, 1990, 1993) and the limitation of detection techniques make it difficult to quantitatively estimate their contribution to methanogenesis directly by experiments with ${ }^{14} \mathrm{C}$-labeled substrates due to poorly defined concentrations in the pore-water and potential exchange of radiotracer between free and adsorbed pools.

The correlation of microbial community profiles with geochemical data has been challenged by factors like limited datasets, low spatial resolution, and insufficient depth of the taxonomic profiling (Jørgensen et al., 2012). In our study, highest $\mathrm{CH}_{4}$ production rates co-occured with highest methanogen abundance at $0-2 \mathrm{~cm}$ depth. However, the high proportions of hydrogenotrophic methanogens, together with the methylotrophic methanogens in sulfate-rich sediments, deviated from our original hypothesis that methylotrophic methanogens should dominate there. We do not know whether these hydrogenotrophic methanogens were actually active or not. The potential methylotrophic methanogens (e.g., uncultivated members of the phylum Bathyarchaeota) also remain to be characterized and verified, though environmental genomics have indicated their potential for methanogenesis (Evans et al., 2015; Du Toit, 2016; Lever, 2016; Nobu et al., 2016; Vanwonterghem et al., 2016). On the other hand, the presence of hydrogenotrophic methanogens in the uppermost sediment might indicate that 
methanogens could still produce $\mathrm{CH}_{4}$ through this pathway even when the sulfate concentration is high, which has been demonstrated in moving bed biofilm reactors (Yang et al., 2015). These methanogens may have benefited from the heterogeneous and fluctuating redox conditions generated by bioturbation in the surface sediment, where sulfate reducers cannot effectively inhibit hydrogenotrophic methanogens through substrate competition (Kristensen et al., 2012; Chen, 2015). It is also possible that hydrogen leakage from methylotrophic methanogens enhanced hydrogenotrophic methanogenesis, a syntrophy which was previously found by co-culturing of a sulfate-reducer with hydrogenotrophic methanogens and methylotrophic methanogens (Finke et al., 2007; Ozuolmez et al., 2015).

The depth decrease of $\mathrm{CH}_{4}$ oxidation rate in the present study was similar to earlier research in the near-by Kysing Fjord in July (Iversen and Blackburn, 1981). Those authors directly quantified $\mathrm{CH}_{4}$ oxidation rates by determining the production of ${ }^{14} \mathrm{CO}_{2}$ from injected ${ }^{14} \mathrm{CH}_{4}$ during sediment incubations, and found the highest $\mathrm{CH}_{4}$ oxidation rate of $\sim 180$ pmol cm$~^{-3} \mathrm{~d}^{-1}$ in $0-2 \mathrm{~cm}$. In our study, the sediment was sectioned and sieved in an anaerobic glove box under a nitrogen gas atmosphere. Oxygen was therefore depleted in these sediments during the processing and stabilization of bag incubations, and anaerobic carbon mineralization should dominate in these bags (Thamdrup and Canfield, 1996). Sulfate was probably the most important electron acceptor due to its high concentration, and high activity of sulfate-reducing microbes in the sediment (Figure 5, left panel), however, the difference between DIC production rates and SRR-related mineralization rate in the top $2 \mathrm{~cm}$ (Figure 5, right panel) indicated that other electron acceptors like nitrate or ferric iron, which were not directly quantified in the present study, might also play a role in this layer. Nevertheless, we can still speculate that nitrate and iron-dependent anaerobic methane oxidation, which are thermodynamically favorable and for which microbial players have been found (Ettwig et al., 2010, 2016; Timmers et al., 2017), might have also been relevant during our bag incubations. The methane turnover rates over $0-16 \mathrm{~cm}$ were less than $0.2 \%$ of the total carbon mineralization rates, but the integrated rates over $0-16 \mathrm{~cm}$ were comparable to the $\mathrm{CH}_{4}$ flux rates calculated from $\mathrm{CH}_{4}$ profiles (Table 1), which was also shown in Maltby et al. (2016), implying that the methane turnover in surface sediment may play a more important role in $\mathrm{CH}_{4}$ exchange between sediment and above water than previously thought.

\section{REFERENCES}

Alcolombri, U., Ben-Dor, S., Feldmesser, E., Levin, Y., Tawfik, D. S., and Vardi, A. (2015). Identification of the algal dimethyl sulfide-releasing enzyme: a missing link in the marine sulfur cycle. Science 348, 1466-1469. doi: 10.1126/science. aab1586

Alperin, M. J., Reeburgh, W. S., and Whiticar, M. J. (1988). Carbon and hydrogen isotope fractionation resulting from anaerobic methane oxidation. Global. Biogeochem. Cycles 2, 279-288. doi: 10.1029/GB002i003p00279

\section{CONCLUSION}

Methanogenesis was found in marine surface sediment, which so far has eluded direct observation of methane profiles. This methane production was closely coupled to methane oxidation, leading to a cryptic methane cycling in marine surface sediment. Considering the common environmental conditions found in other coastal systems, we speculate that such a cryptic methane cycling can be ubiquitous but further work is needed to elucidate the role of different groups of methanogens and methanotrophs involved.

\section{AUTHOR CONTRIBUTIONS}

NR-P, BJ, and K-QX designed the study; K-QX and FB collected the sample, did the geochemical measurement, and analyzed the data; K-QX and KK did the molecular analysis; K-QX wrote the paper; all co-authors reviewed the paper.

\section{FUNDING}

The research received funding from the AU ForskningsFond AU IDEAS, the EU FP7 ERC Grant Agreement $n^{\circ}$ [294200], and the Danish National Research Foundation grant Agreement $\mathrm{n}^{\circ}$ [DNRF104].

\section{ACKNOWLEDGMENTS}

We thank Karina Bomholt Oest, Jeanette Pedersen, Britta Poulsen, and Susanne Nielsen (Aarhus University) for analytical work and technical support. We are especially grateful to Hans Røy, Captain Torben Vang, and the crew of the RV Aurora of Aarhus University for outstanding support during the Aarhus Bay sampling campaigns.

\section{SUPPLEMENTARY MATERIAL}

The Supplementary Material for this article can be found online at: http://journal.frontiersin.org/article/10.3389/fmicb. 2017.01198/full\#supplementary-material

Andersen, B. L., Bidoglio, G., Leip, A., and Rembges, D. (1998). A new method to study simultaneous methane oxidation and methane production in soils. Global. Biogeochem. Cycles 12, 587-594. doi: 10.1029/ $98 \mathrm{gb} 01975$

Blackburn, T. H. (1979). Method for measuring rates of NH4+ turnover in anoxic marine sediments, using a $15 \mathrm{~N}-\mathrm{NH} 4+$ dilution technique. Appl. Environ. Microb. 37, 760-765.

Boudreau, B. P. (1997). Diagenetic Models and Their Implementation. Berlin: Springer. doi: 10.1007/978-3-642-60421-8 
Bower, C. E., and Holm-Hansen, T. (1980). A salicylate-hypochlorite method for determining ammonia in seawater. Can. J. Fish. Aquat. Sci. 37, 794-798. doi: 10.1139/f80-106

Canfield, D. E. (1989). Reactive iron in marine sediments. Geochim. Cosmochim. Acta 53, 619-632. doi: 10.1016/0016-7037(89)90005-7

Canfield, D. E., Jørgensen, B. B., Fossing, H., Glud, R., Gundersen, J., Ramsing, N. B., et al. (1993a). Pathways of organic carbon oxidation in three continental margin sediments. Mar. Geol. 113, 27-40. doi: 10.1016/0025-3227(93) 90147-N

Canfield, D. E., Thamdrup, B., and Hansen, J. W. (1993b). The anaerobic degradation of organic matter in Danish coastal sediments: iron reduction, manganese reduction, and sulfate reduction. Geochim. Cosmochim. Acta 57, 3867-3883. doi: 10.1016/0016-7037(93)90340-3

Canfield, D. E., Kristensen, E., and Thamdrup, B. (2005). Aquatic Geomicrobiology. Houston: Gulf Professional Publishing.

Chen, X. (2015). Controls on Microbial Community Zonation in Coastal Marine Sediment (Aarhus Bay). Ph.D. thesis, Aarhus University, Aarhus.

Dale, A. W., Aguilera, D. R., Regnier, P., Fossing, H., Knab, N. J., and Jørgensen, B. B. (2008). Seasonal dynamics of the depth and rate of anaerobic oxidation of methane in aarhus bay (Denmark) sediments. J. Mar. Res. 66, 127-155. doi: $10.1357 / 002224008784815775$

DeLong, E. F. (1992). Archaea in coastal marine environments. Proc. Natl. Acad. Sci. U.S.A. 89, 5685-5689. doi: 10.1073/pnas.89.12.5685

Du Toit, A. (2016). Archaeal genomics: divergent methanogenic archaea. Nat. Rev. Microbiol.. 14, 667-667. doi: 10.1038/nrmicro.2016.156

Edgar, R. C., Haas, B. J., Clemente, J. C., Quince, C., and Knight, R. (2011). UCHIME improves sensitivity and speed of chimera detection. Bioinformatics 27, 2194-2200. doi: 10.1093/bioinformatics/btr381

Ettwig, K. F., Butler, M. K., Le Paslier, D., Pelletier, E., Mangenot, S., Kuypers, M. M. M., et al. (2010). Nitrite-driven anaerobic methane oxidation by oxygenic bacteria. Nature 464, 543-548. doi: 10.1038/nature08883

Ettwig, K. F., Zhu, B., Speth, D., Keltjens, J. T., Jetten, M. S. M., and Kartal, B. (2016). Archaea catalyze iron-dependent anaerobic oxidation of methane. Proc. Natl. Acad. Sci. U.S.A. doi: 10.1073/pnas.1609534113 [Epub ahead of print].

Evans, P. N., Parks, D. H., Chadwick, G. L., Robbins, S. J., Orphan, V. J., Golding, S. D., et al. (2015). Methane metabolism in the archaeal phylum Bathyarchaeota revealed by genome-centric metagenomics. Science 350, 434-438. doi: 10.1126/ science.aac7745

Finke, N., Hoehler, T. M., and Jørgensen, B. B. (2007). Hydrogen 'leakage' during methanogenesis from methanol and methylamine: implications for anaerobic carbon degradation pathways in aquatic sediments. Environ. Microbiol. 9, 1060-1071. doi: 10.1111/j.1462-2920.2007.01248.x

Flury, S., Røy, H., Dale, A. W., Fossing, H., Tóth, Z., Spiess, V., et al. (2016). Controls on subsurface methane fluxes and shallow gas formation in baltic sea sediment (aarhus bay. denmark). Geochim. Cosmochim. Acta 188, 297-309. doi: 10.1016/j.gca.2016.05.037

Glombitza, C., Pedersen, J., Røy, H., and Jørgensen, B. B. (2014). Direct analysis of volatile fatty acids in marine sediment porewater by two-dimensional ion chromatography-mass spectrometry. Limnol. Oceanogr. Methods 12, 455-468. doi: 10.4319/lom.2014.12.455

Goodfellow, M., and Stackebrandt, E. (1991). Nucleic Acid Techniques in Bacterial Systematics. Hoboken, NJ: J. Wiley.

Hansen, J. W., Thamdrup, B., and Jørgensen, B. B. (2000). Anoxic incubation of sediment in gas-tight plastic bags: a method for biogeochemical process studies. Mar. Ecol-Prog. Ser. 208, 273-282. doi: 10.3354/meps208273

Hansen, L. B., Finster, K., Fossing, H., and Iversen, N. (1998). Anaerobic methane oxidation in sulfate depleted sediments: effects of sulfate and molybdate additions. Aquat. Microb. Ecol. 14, 195-204. doi: 10.3354/ ame014195

Hoehler, T. M., Alperin, M. J., Albert, D. B., and Martens, C. S. (1998). Thermodynamic control on hydrogen concentrations in anoxic sediments. Geochim. Cosmochim. Acta 62, 1745-1756. doi: 10.1016/S0016-7037(98) 00106-9

Iversen, N., and Blackburn, T. H. (1981). Seasonal rates of methane oxidation in anoxic marine-sediments. Appl. Environ. Microb. 41, 1295-1300.

Jabłoński, S., Rodowicz, P., and Łukaszewicz, M. (2015). Methanogenic archaea database containing physiological and biochemical characteristics. Int. J. Syst. Evol. Microbiol. 65, 1360-1368. doi: 10.1099/ijs.0.000065
Jørgensen, B. B. (1978). A comparison of methods for the quantification of bacterial sulfate reduction in coastal marine sediments. Geomicrobiol. J. 1, 11-27. doi: 10.1080/01490457809377721

Jørgensen, S. L., Hannisdal, B., Lanzén, A., Baumberger, T., Flesland, K., Fonseca, R., et al. (2012). Correlating microbial community profiles with geochemical data in highly stratified sediments from the arctic mid-ocean ridge. Proc. Natl. Acad. Sci. U.S.A. 109, E2846-E2855. doi: 10.1073/pnas.1207574109

Kallmeyer, J., Ferdelman, T. G., Weber, A., Fossing, H., and Jørgensen, B. B. (2004). A cold chromium distillation procedure for radiolabeled sulfide applied to sulfate reduction measurements. Limnol. Oceanogr. Methods. 2, 171-180. doi: 10.4319/lom.2004.2.171

Kanneworff, E., and Nicolaisen, W. (1972). The "Haps" a frame-supported bottom corer. Ophelia 10, 119-128. doi: 10.1080/00785326.1972.10430108

Kelley, C. A., Chanton, J. P., and Bebout, B. M. (2015). Rates and pathways of methanogenesis in hypersaline environments as determined by 13C-labeling. Biogeochemistry 126, 329-341. doi: 10.1007/s10533-015-0161-9

Kelley, C. A., Nicholson, B. E., Beaudoin, C. S., Detweiler, A. M., and Bebout, B. M. (2014). Trimethylamine and organic matter additions reverse substrate limitation effects on the $\delta 13 \mathrm{C}$ values of methane produced in hypersaline microbial mats. Appl. Environ. Microbiol. 80, 7316-7323. doi: 10.1128/aem. 02641-14

Kiene, R. P., Oremland, R. S., Catena, A., Miller, L. G., and Capone, D. G. (1986). Metabolism of reduced methylated sulfur compounds in anaerobic sediments and by a pure culture of an estuarine methanogen. Appl. Environ. Microbiol. 52, 1037-1045.

King, G. M. (1984). Metabolism of trimethylamine, choline, and glycine betaine by sulfate-reducing and methanogenic bacteria in marine sediments. Appl. Environ. Microbiol. 48, 719-725.

Klindworth, A., Pruesse, E., Schweer, T., Peplies, J., Quast, C., Horn, M., et al. (2013). Evaluation of general 16S ribosomal RNA gene PCR primers for classical and next-generation sequencing-based diversity studies. Nucleic. Acids. Res. 41:e1. doi: 10.1093/nar/gks808

Knittel, K., and Boetius, A. (2009). Anaerobic oxidation of methane: progress with an unknown process. Annu. Rev. Microbiol. 63, 311-334. doi: 10.1146/annurev. micro.61.080706.093130

Kozich, J. J., Westcott, S. L., Baxter, N. T., Highlander, S. K., and Schloss, P. D. (2013). Development of a dual-index sequencing strategy and curation pipeline for analyzing amplicon sequence data on the MiSeq Illumina sequencing platform. Appl. Environ. Microbol. 79, 5112-5120. doi: 10.1128/AEM.01043-13

Kristensen, E., Dias-Lopes, G., Delefosse, M., Valdemarsen, T., Quintana, C., Banta, G. T., et al. (2012). What is bioturbation? The need for a precise definition for fauna in aquatic sciences. Mar. Ecol-Prog. Ser. 446, 285-302. doi: 10.3354/ meps09506

Langerhuus, A. T., Røy, H., Lever, M. A., Morono, Y., Inagaki, F., Jørgensen, B. B., et al. (2012). Endospore abundance and d:l-amino acid modeling of bacterial turnover in holocene marine sediment (Aarhus Bay). Geochim. Cosmochim. Acta 99, 87-99. doi: 10.1016/j.gca.2012.09.023

Lever, M. A. (2016). A new era of methanogenesis research. Trends. Microbiol. 24, 84-86. doi: 10.1016/j.tim.2015.12.005

Lovley, D. R., and Goodwin, S. (1988). Hydrogen concentrations as an indicator of the predominant terminal electron-accepting reactions in aquatic sediments. Geochim. Cosmochim. Acta 52, 2993-3003. doi: 10.1016/0016-7037(88)90163-9

Lovley, D. R., and Klug, M. J. (1983). Sulfate reducers can outcompete methanogens at freshwater sulfate concentrations. Appl. Environ. Microbiol. 45, 187-192.

Maltby, J., Sommer, S., Dale, A. W., and Treude, T. (2016). Microbial methanogenesis in the sulfate-reducing zone of surface sediments traversing the Peruvian margin. Biogeosciences 13, 283-299. doi: 10.5194/bg-13-283-2016

Meischner, D., and Rumohr, J. (1974). A light-weight, high-momentum gravity corer for subaqueous sediments. Senckenb. Marit. 6, 105-117.

Meng, J., Xu, J., Qin, D., He, Y., Xiao, X., and Wang, F. (2014). Genetic and functional properties of uncultivated MCG archaea assessed by metagenome and gene expression analyses. ISME. J. 8, 650-659. doi: 10.1038/ismej. 2013.174

Mitterer, R. M. (2010). Methanogenesis and sulfate reduction in marine sediments: a new model. Earth. Planet. Sci. Lett. 295, 358-366. doi: 10.1016/j.epsl.2010. 04.009

Mitterer, R. M., Malone, M. J., Goodfriend, G. A., Swart, P. K., Wortmann, U. G., Logan, G. A., et al. (2001). Co-generation of hydrogen sulfide and methane in 
marine carbonate sediments. Geophys. Res. Lett. 28, 3931-3934. doi: 10.1029/ 2001 gl013320

Nobu, M. K., Narihiro, T., Kuroda, K., Mei, R., and Liu, W.-T. (2016). Chasing the elusive euryarchaeota class WSA2: genomes reveal a uniquely fastidious methyl-reducing methanogen. ISME. J. 10, 2478-2487. doi: 10.1038/ismej. 2016.33

Oremland, R. S., Marsh, L. M., and Polcin, S. (1982). Methane production and simultaneous sulphate reduction in anoxic, salt marsh sediments. Nature 296, 143-145. doi: 10.1038/296143a0

Ozuolmez, D., Na, H., Lever, M. A., Kjeldsen, K. U., Jorgensen, B. B., and Plugge, C. M. (2015). Methanogenic archaea and sulfate reducing bacteria co-cultured on acetate: teamwork or coexistence? Front. Microbiol. 6:492. doi: 10.3389/ fmicb.2015.00492

Quast, C., Pruesse, E., Yilmaz, P., Gerken, J., Schweer, T., Yarza, P., et al. (2013). The SILVA ribosomal RNA gene database project: improved data processing and web-based tools. Nucleic Acids Res. 41, D590-D596. doi: 10.1093/nar/gks1219

Rasmussen, H., and Jørgensen, B. B. (1992). Microelectrode studies of seasonal oxygen uptake in a coastal sediment: role of molecular diffusion. Mar. Ecol-Prog. Ser. 81, 289-303. doi: 10.3354/meps081289

Reeburgh, W. S. (2007). Oceanic methane biogeochemistry. Chem. Rev. 107, 486-513. doi: $10.1021 / \mathrm{cr} 050362 \mathrm{v}$

Revsbech, N. P. (1989). An oxygen microsensor with a guard cathode. Limnol. Oceanogr. 34, 474-478. doi: 10.4319/lo.1989.34.2.0474

Rice, A. L., Gotoh, A. A., Ajie, H. O., and Tyler, S. C. (2001). High-precision continuous-flow measurement of $\delta 13 \mathrm{C}$ and $\delta \mathrm{D}$ of atmospheric $\mathrm{CH} 4$. Anal. Chem. 73, 4104-4110. doi: 10.1021/ac0155106

Schloss, P. D., Westcott, S. L., Ryabin, T., Hall, J. R., Hartmann, M., Hollister, E. B., et al. (2009). Introducing mothur: open-source, platform-independent, community-supported software for describing and comparing microbial communities. Appl. Environ. Microbiol. 75, 7537-7541. doi: 10.1128/aem. 01541-09

Schönheit, P., Kristjansson, J. K., and Thauer, R. K. (1982). Kinetic mechanism for the ability of sulfate reducers to out-compete methanogens for acetate. Arch. Microbiol. 132, 285-288. doi: 10.1007/bf00407967

Seifert, R., Nauhaus, K., Blumenberg, M., Krüger, M., and Michaelis, W. (2006). Methane dynamics in a microbial community of the Black Sea traced by stable carbon isotopes in vitro. Org. Geochem. 37, 1411-1419. doi: 10.1016/j. orggeochem.2006.03.007

Takai, K., and Horikoshi, K. (2000). Rapid detection and quantification of members of the archaeal community by quantitative PCR using fluorogenic probes. Appl. Environ. Microbiol. 66, 5066-5072. doi: 10.1128/aem.66.11.5066-5072.2000

Thamdrup, B., and Canfield, D. E. (1996). Pathways of carbon oxidation in continental margin sediments off central Chile. Limnol. Oceanogr. 41, 1629-1650. doi: 10.4319/lo.1996.41.8.1629

Timmers, P. H. A., Welte, C. U., Koehorst, J. J., Plugge, C. M., Jetten, M. S. M., and Stams, A. J. M. (2017). Reverse methanogenesis and respiration in methanotrophic archaea. Archaea 2017:22. doi: 10.1155/2017/1654237

Torres, M. E., Mix, A. C., and Rugh, W. D. (2005). Precise $\delta 13 \mathrm{C}$ analysis of dissolved inorganic carbon in natural waters using automated headspace sampling and continuous-flow mass spectrometry. Limnol. Oceanogr. Methods 3, 349-360. doi: 10.4319/lom.2005.3.349

Valentine, D. L. (2011). Emerging topics in marine methane biogeochemistry. Annu. Rev. Mar. Sci. 3, 147-171. doi: 10.1146/annurev-marine-120709-142734
Vanwonterghem, I., Evans, P. N., Parks, D. H., Jensen, P. D., Woodcroft, B. J., Hugenholtz, P., et al. (2016). Methylotrophic methanogenesis discovered in the archaeal phylum Verstraetearchaeota. Nat. Microbiol. 1:16170. doi: 10.1038/ nmicrobiol.2016.170

Vigneron, A., L'Haridon, S., Godfroy, A., Roussel, E. G., Cragg, B. A., Parkes, R. J., et al. (2015). Evidence of active methanogen communities in shallow sediments of the sonora margin cold seeps. Appl. Environ. Microbiol. 81, 3451-3459. doi: 10.1128/aem.00147-15

von Fischer, J. C., and Hedin, L. O. (2002). Separating methane production and consumption with a field-based isotope pool dilution technique. Global. Biogeochem. Cycle 16, 8.1-8.13. doi: 10.1029/2001gb001448

Wang, X.-C., and Lee, C. (1990). The distribution and adsorption behavior of aliphatic amines in marine and lacustrine sediments. Geochim. Cosmochim. Acta 54, 2759-2774. doi: 10.1016/0016-7037(90)90010-I

Wang, X.-C., and Lee, C. (1993). Adsorption and desorption of aliphatic amines, amino acids and acetate by clay minerals and marine sediments. Mar. Chem. 44, 1-23. doi: 10.1016/0304-4203(93)90002-6

Whitman, W. B., Bowen, T. L., and Boone, D. R. (2006). "The methanogenic bacteria," in The Prokaryotes: Archaea. Bacteria: Firmicutes, Actinomycetes, Vol. 3, eds M. Dworkin, S. Falkow, E. Rosenberg, K.-H. Schleifer, and E. Stackebrandt (New York, NY: Springer), 165-207.

Yamamoto, S., Alcauskas, J. B., and Crozier, T. E. (1976). Solubility of methane in distilled water and seawater. J. Chem. Eng. Data 21, 78-80. doi: 10.1021/ je60068a029

Yancey, P. H., and Somero, G. N. (1980). Methylamine osmoregulatory solutes of elasmobranch fishes counteract urea inhibition of enzymes. J. Exp. Zool. 212, 205-213. doi: 10.1002/jez.1402120207

Yang, S.-L., Tang, Y.-Q., Gou, M., and Jiang, X. (2015). Effect of sulfate addition on methane production and sulfate reduction in a mesophilic acetate-fed anaerobic reactor. Appl. Microbiol. Biotechnol. 99, 3269-3277. doi: 10.1007/s00253-0146235-0

Yilmaz, P., Parfrey, L. W., Yarza, P., Gerken, J., Pruesse, E., Quast, C., et al. (2014). The SILVA and "all-species living tree project (LTP)" taxonomic frameworks. Nucleic Acids Res. 42, D643-D648. doi: 10.1093/nar/gkt1209

Zhuang, G.-C. (2014). Methylotrophic Methanogenesis and Potential Methylated Substrates in Marine Sediment. Ph.D. thesis, University of Bremen, Bremen.

Zhuang, G. C., Elling, F. J., Nigro, L. M., Samarkin, V., Joye, S. B., Teske, A., et al. (2016). Multiple evidence for methylotrophic methanogenesis as the dominant methanogenic pathway in hypersaline sediments from the Orca Basin, Gulf of Mexico. Geochim. Cosmochim. Acta 187, 1-20. doi: 10.1016/j.gca.2016. 05.005

Conflict of Interest Statement: The authors declare that the research was conducted in the absence of any commercial or financial relationships that could be construed as a potential conflict of interest.

Copyright (c) 2017 Xiao, Beulig, Kjeldsen, Jørgensen and Risgaard-Petersen. This is an open-access article distributed under the terms of the Creative Commons Attribution License (CC BY). The use, distribution or reproduction in other forums is permitted, provided the original author(s) or licensor are credited and that the original publication in this journal is cited, in accordance with accepted academic practice. No use, distribution or reproduction is permitted which does not comply with these terms. 